Check for updates

Cite this: RSC Adv., 2018, 8, 26283

Received 9th December 2017

Accepted 10th July 2018

DOI: $10.1039 / c 7 r a 13178 j$

rsc.li/rsc-advances

\section{Experimental and model research on chloride ion gas-solid distribution in the process of desulfurization wastewater evaporation}

\author{
Ma Shuangchen, (DD *a Chai Jin, ${ }^{\text {a }}$ Wu Kai, ${ }^{a}$ Xiang Yajun, ${ }^{a}$ Wan Zhongcheng ${ }^{b}$ \\ and Zhang Jingrui ${ }^{\mathrm{b}}$
}

In this paper, research on chloride ion gas-solid distribution in the process of desulfurization wastewater evaporation was carried out. The factor analysis of temperature, $\mathrm{pH}$, and concentrations of $\mathrm{Cl}^{-} \mathrm{Na}^{+}, \mathrm{Ca}^{2+}$ and $\mathrm{Mg}^{2+}$ was explored by orthogonal experiments. Results show that the distribution coefficient increases with increasing temperature and $\mathrm{Mg}^{2+}$ concentration and decreasing $\mathrm{pH}$, but decreases with increasing concentrations of $\mathrm{Cl}^{-}, \mathrm{Ca}^{2+}$ and $\mathrm{Na}^{+}$; The interaction and significance of each factor were compared and analyzed, and the order of influence significance on the chloride ion gas-solid distribution coefficient is listed as: temperature $(0.781)>\mathrm{pH}(0.611)>\mathrm{Cl}^{-}$concentration $(0.366)>\mathrm{Mg}^{2+}$ concentration (0.211) $>\mathrm{Ca}^{2+}$ concentration (0.079) $>\mathrm{Na}^{+}$concentration (0.03). A chloride ion gas-solid phase distribution coefficient model ranging from $180{ }^{\circ} \mathrm{C}$ to $380{ }^{\circ} \mathrm{C}$ was built based on phase equilibrium theory and state equations. The study clarifies the gas phase transformation mechanism of chloride ions, and achieves the quantification and prediction of chloride ion volatilization under different environmental and water quality parameters; an important theoretical and practical reference for the application of high temperature flue gas evaporation technology is provided through the research.

\section{Introduction}

The wet limestone-gypsum flue gas desulfurization process is adopted in most coal-fired power plants in China to remove $\mathrm{SO}_{2}{ }^{1,2}$ In terms of this technology, the desulfurization wastewater needs to be discharged periodically to keep the chloride ion concentration under $20000 \mathrm{mg} \mathrm{L}^{-1}$, thereby protecting the desulfurization system from corrosion and maintaining the normal operation of the desulfurization system..$^{3-6}$ The water quality of desulfurization wastewater is shown as follows:

(1) The desulfurization wastewater is weakly acidic; the $\mathrm{pH}$ value remains at 4.5-6.5.

(2) The desulfurization wastewater has high content of suspended solids (SS) and turbidity; the main SS species are gypsum particles and $\mathrm{SiO}_{2}$.

(3) The desulfurization wastewater contains a variety of heavy metals, such as $\mathrm{Cr}, \mathrm{As}, \mathrm{Cd}, \mathrm{Pb}, \mathrm{Hg}$ and so on.

(4) The total dissolved solids (TDS) in wastewater is high; the anions are mainly $\mathrm{Cl}^{-}$and $\mathrm{SO}_{4}{ }^{2-}$ and cations are mainly $\mathrm{Ca}^{2+}$ and $\mathrm{Mg}^{2+}$.

With respect to desulfurization wastewater treatment, previous studies mainly focused on single pollutant removal

${ }^{a}$ School of Environmental Science and Engineering, North China Electric Power University (Baoding), Baoding, 071003, He Bei province, China.E-mail: msc1225@ 163.com; Tel: +86-3127525521

${ }^{b}$ Shengfa Environmental Protection Co., XiaMen, 361000, Fu Jian province, China and membrane purification to meet the discharge or reuse standards. Yong H. Huang explored the removal performance of heavy metals in desulfurization wastewater using hybrid zerovalent iron. ${ }^{7,8}$ The results revealed that the removal efficiencies of $\mathrm{Se}$ and $\mathrm{Hg}$ were more than 99\%; Lin Cui studied electrolysis-electrodialysis process removing chloride ion from wet flue gas desulfurization wastewater and the removal efficiency reached $83.3 \%{ }^{9}{ }^{9} \mathrm{Na}$ Yin investigated the process feasibility of ultrafiltration-nanofiltration-reverse osmosis applying for desulfurization wastewater treatment, which could produce sulfuric acid and ammonium salt at the same time, results showed that the process could treat desulfurization wastewater to the discharge standard and the by-product purity was high. ${ }^{\mathbf{1 0}}$ On April 16, 2015, the State Council of China issued the "Water Pollution Control Action Plan", to emphasize the management of various types of water pollution. As the terminal wastewater in power plants, desulfurization wastewater has complex components and water quality is poor. Zero liquid discharge (ZLD) of desulfurization wastewater is required by Environmental Protection Departments in some regions. ${ }^{\mathbf{1 1}}$ Under this background, the technologies of single pollutant removal and membrane purification are difficult to promote owing to their high investment, complex process and high risk of recycling. Thus, a series of ZLD technologies are being developed gradually, the comparison for ZLD technology routines in recent years are shown in Table 1 in detail. ${ }^{12-17}$ 
Two feasible technical routes were put forward to achieve ZLD of desulfurization wastewater in China. Flue gas evaporation drying and crystallization were suggested. ${ }^{18}$ In flue gas evaporation process, the hot flue gas is extracted before airpreheater, and contacts with wastewater droplets atomized by the atomizer, then the droplets are dried by the high temperature flue gas. Finally, the evaporation products return to the original flue duct with flue gas and are caught by downstream dust collector.

Desulfurization wastewater is a mixed salt system with high chloride ion content, resulting in the release of gaseous $\mathrm{HCl}$ in high temperature evaporation process. The gaseous $\mathrm{HCl}$ in flue gas will finally enter into the desulfurization system, it will undoubtedly affect the original desulfurization system chloride ion balance and result in adverse effects. Facing the rapid development of ZLD, how to quantify and predict the gas-solid phase distribution of chloride ion under different working conditions becomes the core problem for application of high temperature flue gas evaporation technology.

As for the phase distribution of chloride ion, J. M. Simonson probed into the gas-liquid phase distribution law of chloride ion from $50{ }^{\circ} \mathrm{C}$ to $350{ }^{\circ} \mathrm{C}$. It was pointed out that the distribution coefficient could be affected by temperature, $\mathrm{pH}$, chloride ion content, salt content, salt composition and other factors; $;^{19-21} \mathrm{M}$. S. Gruszkiewicz and Liu CK combined the phase equilibrium theory and activity coefficient with the dissolution-carryover theory of boiler water under high temperature and high pressure conditions. The results showed that under normal conditions, chloride ion usually volatilized to the gas phase in the form of $\mathrm{HCl}$ and $\mathrm{NH}_{4} \mathrm{Cl}$, but in low ammonia environment, the main species was $\mathrm{HCl}^{22-26}$ Otakar Jonas studied the change of $\mathrm{pH}$ with temperature in pure water. He found that the $\mathrm{pH}$ of pure water showed a decreasing trend with increasing temperature, it reached the minimum $\mathrm{pH}$ of 5.6 at $430{ }^{\circ} \mathrm{C}^{27}$ When $\mathrm{Cl}^{-}$ is contained in water, the $\mathrm{H}^{+}$generated from hydrolysis can easily bind with $\mathrm{Cl}^{-}$, and then volatilize in the form of gaseous $\mathrm{HCl}$. At present, the study of chloride ion heterogeneous distribution model is still scarce, especially, related research on the gas-solid phase distribution is blank. The models available are only gas-liquid phase distribution that J. M. Simonson and M. S. Gruszkiewicz once put forward, but the influence of the key environmental factors and water quality parameters on the distribution in the model come to nothing.

In this paper, the essential effects of the environmental factors and water quality parameters such as temperature, $\mathrm{pH}$, concentrations of $\mathrm{Cl}^{-}, \mathrm{Na}^{+}, \mathrm{Ca}^{2+}$ and $\mathrm{Mg}^{2+}$ on the gas-solid phase distribution coefficient of chloride ion were detected by orthogonal experiment. The interaction and significance of each factor were compared and analyzed. The empirical model containing essential influencing factors was proposed based on the orthogonal experimental data, in combination with the theoretical gas-solid phase distribution coefficient model in process of mass transfer and separation, the correction constant $\varphi$ was determined. Finally, an integrated chloride ion gas-solid phase distribution coefficient model can be calculated ranging from $180{ }^{\circ} \mathrm{C}$ to $380{ }^{\circ} \mathrm{C}$. The study obtains the quantification and prediction of chloride ion volatilization in the 


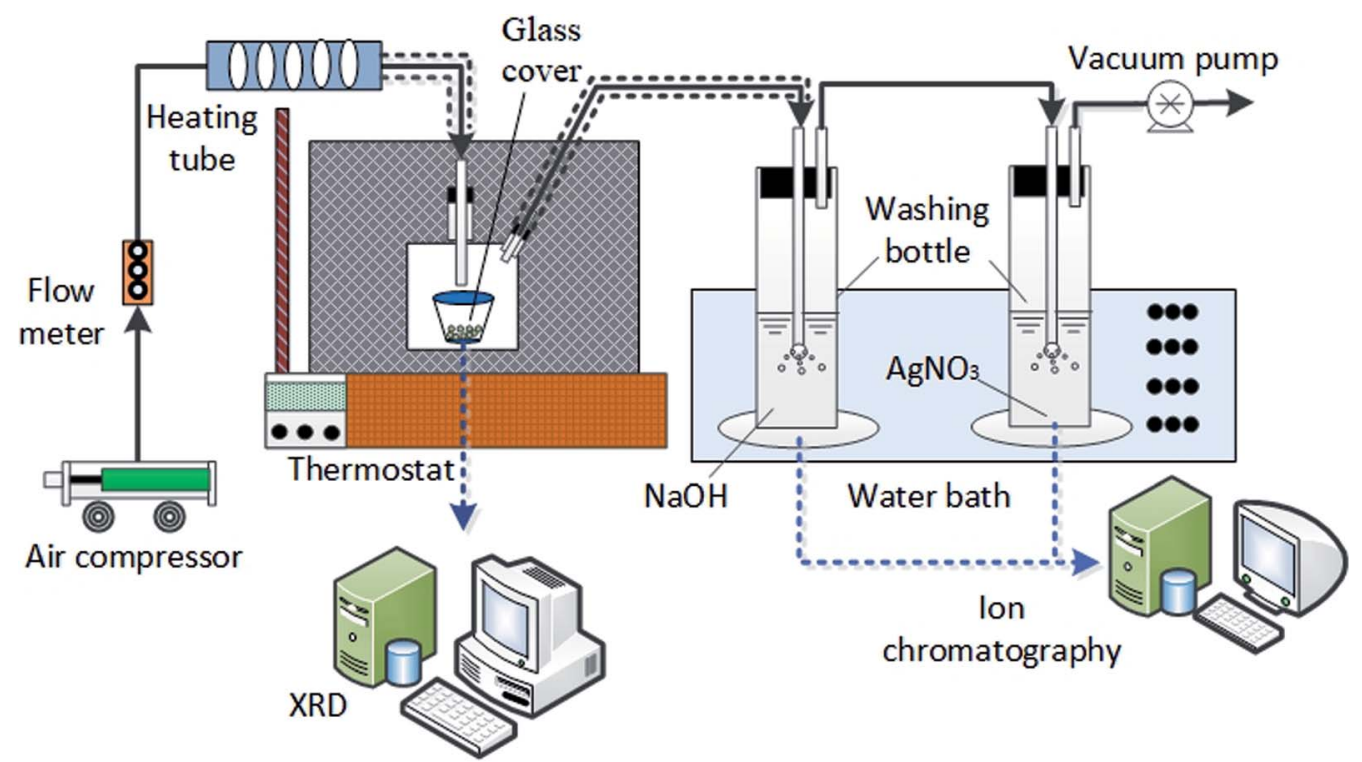

Fig. 1 Experimental system.

process of desulfurization wastewater evaporation, the theoretical basis on chloride ion gas transformation inhibition is established, which provides series of key data and important theoretical reference for the application of high temperature flue gas evaporation technology.

\section{Orthogonal experiment}

\subsection{Experimental system}

The $\mathrm{HCl}$ volatilization experiment was carried out in self-made experimental system as shown in Fig. 1. Experimental equipment consisted of air compressor, flow meter, heating tube, thermostat, self-made glass cover, two washing bottles, water bath, vacuum pump and ion chromatography (IC6000) etc. The measuring span of flow meter was 1-15 $\mathrm{L} \mathrm{min}^{-1}$, the maximum power of heating tube was $12 \mathrm{~kW}$ and the highest heating temperature of thermostat kept at $500{ }^{\circ} \mathrm{C}$, the evaporation product was characterized by online XRD (Bruker D8 advance) and common XRD (TD3500).

\subsection{Experimental method}

Sample solution with constant amount per time was placed in the crucible and heated in the thermostat; the air providing by air compressor was pumped into sealed glass cover after heated by heating tube; glass wool was used to keep constant temperature for the gas; the evaporated gas was discharged to the first washing bottle by the vacuum pump at the end of the experimental system. The volatilized gaseous chloride was absorbed by $\mathrm{NaOH}$ solution in the washing bottle; $\mathrm{AgNO}_{3}$ solution was placed in the second washing bottle to monitor whether the gaseous chloride has been absorbed completely in the first one. The bottles were placed in a thermostatic water bath to maintain a constant absorption temperature; the remaining gas was extracted; flow meter was used to maintain a dynamic equilibrium between the inlet gas from air compressor and the outlet gas through vacuum pump. The dissolved $\mathrm{Cl}^{-}$in the absorption liquid in washing bottle was quantitatively analyzed using IC6000 ion chromatography and the evaporation product was characterized by XRD. The operation conditions of experiment are shown in Table 2.

\section{Results and discussions}

Aiming at six essential effects of environmental factors and water quality parameters such as temperature, $\mathrm{pH}$, concentrations of $\mathrm{Cl}^{-}, \mathrm{Na}^{+}, \mathrm{Ca}^{2+}$ and $\mathrm{Mg}^{2+}$ on the gas-solid phase distribution coefficient of chloride ion, the "Six Factors and Four Levels" orthogonal experiment was designed to compare the interaction and significance of each factor. The mechanism of chloride ion gas phase transformation was analyzed, and the most suitable parameters of controlling the minimum chloride ion gas-solid phase distribution coefficient were obtained. For

Table 2 Experimental parameters

\begin{tabular}{|c|c|}
\hline Condition & Parameter \\
\hline Temperature, ${ }^{\circ} \mathrm{C}$ & $180-380$ \\
\hline $\mathrm{pH}$ & $3.0-9.0$ \\
\hline $\mathrm{Cl}^{-}$concentration, $\mathrm{mol} \mathrm{L}^{-1}$ & $0.01-0.04$ \\
\hline TDS, $\mathrm{mg} \mathrm{L}^{-1}$ & $2645-10580$ \\
\hline Absorption solution volume, $\mathrm{mL}$ & 200 \\
\hline Absorption solution concentration, $\mathrm{mol} \mathrm{L}^{-1}$ & 0.04 \\
\hline Detection solution volume, $\mathrm{mL}$ & 200 \\
\hline Detection solution volume, $\mathrm{mol} \mathrm{L}^{-1}$ & 0.01 \\
\hline Temperature of water bath, ${ }^{\circ} \mathrm{C}$ & 20 \\
\hline Sample volume, $\mathrm{mL}$ & 10 \\
\hline Air flow rate, $\mathrm{L} \mathrm{h}^{-1}$ & $600-800$ \\
\hline IC import flow rate, $\mathrm{mL} \min ^{-1}$ & 0.8 \\
\hline IC inhibition current, $\mathrm{mA}$ & 40 \\
\hline Online XRD temperature, ${ }^{\circ} \mathrm{C}$ & $150-350$ \\
\hline
\end{tabular}


Table 3 Orthogonal experimental results

\begin{tabular}{lllllll}
\hline Factors & $T(\mathrm{~A}){ }^{\circ} \mathrm{C}$ & $\mathrm{pH}(\mathrm{B})$ & $\mathrm{Cl}^{-}(\mathrm{C}) \mathrm{mol} \mathrm{L}^{-1}$ & $\mathrm{Na}^{+}(\mathrm{D}) \mathrm{mol} \mathrm{L}^{-1}$ & $\mathrm{Ca}^{2+}(\mathrm{E}) \mathrm{mol} \mathrm{L}^{-1}$ & 0.609 \\
$K_{i j}$ & 0.067 & 0.843 & 0.731 & 0.582 & 0.553 & 0.443 \\
$K_{i j}$ & 0.582 & 0.708 & 0.692 & 0.560 & 0.557 & 0.498 \\
$K_{i j}$ & 0.753 & 0.466 & 0.430 & 0.552 & 0.530 & 0.654 \\
$K_{i j}$ & 0.848 & 0.232 & 0.395 & 0.035 & 0.079 & 0.654 \\
$N_{j}$ & 0.781 & 0.611 & 0.336 & & & 0.211 \\
\hline
\end{tabular}

convenient calculation, the chloride ion gas-solid phase distribution coefficient is defined as $K_{\mathrm{Cl}^{-}-\text {Salt }}$, and $\log K_{\mathrm{Cl}^{-}-\text {Salt }}$ is set as the dependent variable. $\log K_{\mathrm{Cl}^{-} \text {-Salt }}$ is calculated by the formula as follows.

$$
\log K_{\mathrm{Cl}^{-}-\text {Salt }}=\log \frac{100\left(\sum C_{\mathrm{absorption}}^{\mathrm{Cl}}-\sum C_{\mathrm{blank}}^{\mathrm{Cl}}\right)}{\sum C_{\text {Sample }}^{\mathrm{Cl}}-\sum C_{\mathrm{absorption}}^{\mathrm{Cl}}}
$$

where $\sum C_{\text {absorption }}^{\mathrm{Cl}}$ is the $\mathrm{Cl}^{-}$concentration in absorption solution; $\sum C_{\text {blank }}^{\mathrm{Cl}}$ is the $\mathrm{Cl}^{-}$concentration in blank control experiment and the value is $2.39 \mathrm{mg} \mathrm{L}^{-1}$ from repeated experiments more than twice; $\sum C_{\text {Sample }}^{\mathrm{Cl}}$ is the $\mathrm{Cl}^{-}$concentration in original sample.

The results of range are analyzed according to the results shown in table above, the significance of various factors on the chloride ion gas-solid phase distribution coefficient can be compared from the size of $N$ value. The order is: $N_{1}(0.781)>N_{2}$ $(0.611)>N_{3}(0.366)>N_{6}(0.211)>N_{5}(0.079)>N_{4}(0.03)$, that is to say temperature is the most dominant influencing factor for chloride ion gas-solid phase distribution coefficient, followed by $\mathrm{pH}$ and $\mathrm{Cl}^{-}$concentration. As for the cations containing in the water, $\mathrm{Mg}^{2+}$ is the most significant one, followed by $\mathrm{Ca}^{2+}$ and $\mathrm{Na}^{+}$, compared with temperature and $\mathrm{pH}$, the others are secondary. Therefore, in the actual operation process, the temperature and $\mathrm{pH}$ should be properly regulated during the evaporation process of desulfurization wastewater in order to relieve the harm caused by chloride ion gas phase transformation (Table 3).

The horizontal values $K_{i j}$ of six factors are analyzed. The $K_{i j}$ is the average of experimental results for each group of factors, it stands for different levels effects of each factor on chloride ion gas-solid phase distribution. It can be seen from the table that

Table 4 Analysis of variance

\begin{tabular}{|c|c|c|c|c|c|}
\hline Factors & $\begin{array}{l}\text { Sum of deviance } \\
\text { square }\end{array}$ & Degree of freedom & $F$ ratio & $\begin{array}{l}\text { Critical value } \\
F_{a=0.1}\end{array}$ & Significance \\
\hline $\mathrm{T}$ & 2.909 & 3 & 4.337 & -1.000 & $* * * * * *$ \\
\hline $\mathrm{Cl}^{-}$ & 0.726 & 3 & 1.082 & -1.000 & $* * * *$ \\
\hline $\mathrm{Na}^{+}$ & 0.004 & 3 & 0.006 & -1.000 & $*$ \\
\hline $\mathrm{Ca}^{2+}$ & 0.027 & 3 & 0.040 & -1.000 & $* *$ \\
\hline Factors & $\begin{array}{l}\text { Sum of deviance } \\
\text { square }\end{array}$ & Degree of freedom & $F$ ratio & $\begin{array}{l}\text { Critical value } \\
F_{a=0.05}\end{array}$ & Significance \\
\hline $\mathrm{T}$ & 2.909 & 3 & 4.337 & 2.960 & * \\
\hline $\mathrm{pH}$ & 1.747 & 3 & 2.604 & 2.960 & \\
\hline Errors & 6.04 & 27 & & & \\
\hline Factors & $\begin{array}{l}\text { Sum of deviance } \\
\text { square }\end{array}$ & Degree of freedom & $F$ ratio & $\begin{array}{l}\text { Critical value } \\
F_{a=0.01}\end{array}$ & Significance \\
\hline $\mathrm{T}$ & 2.909 & 3 & 4.337 & 4.600 & \\
\hline $\mathrm{pH}$ & 1.747 & 3 & 2.604 & 4.600 & \\
\hline $\mathrm{Cl}^{-}$ & 0.726 & 3 & 1.082 & 4.600 & \\
\hline $\mathrm{Na}^{+}$ & 0.004 & 3 & 0.006 & 4.600 & \\
\hline $\mathrm{Ca}^{2+}$ & 0.027 & 3 & 0.040 & 4.600 & \\
\hline $\mathrm{Mg}^{2+}$ & 0.282 & 3 & 0.420 & 4.600 & \\
\hline Errors & 6.04 & 27 & & & \\
\hline
\end{tabular}


in the factor of temperature, $K_{41}>K_{31}>K_{21}>K_{11}$; in the pH factor, $K_{12}>K_{22}>K_{32}>K_{42}$; as for the $\mathrm{Cl}^{-}$concentration, $K_{13}>$ $K_{23}>K_{33}>K_{43}$; in $\mathrm{Na}^{+}$concentration, $K_{14}>K_{24}>K_{44}>K_{34}$; in $\mathrm{Ca}^{2+}$ factor, $K_{15}>K_{35}>K_{25}>K_{45}$; in the factor of $\mathrm{Mg}^{2+}$ concentration, $K_{46}>K_{36}>K_{26}>K_{16}$. So, the optimal technological parameters for reducing the chloride ion gas-solid phase distribution coefficient are in the following, i.e., temperature $200{ }^{\circ} \mathrm{C}, \mathrm{pH} 9.0, \mathrm{Cl}^{-}$concentration $0.04 \mathrm{~mol} \mathrm{~L}{ }^{-1}, \mathrm{Na}^{+}$concentration $0.03 \mathrm{~mol} \mathrm{~L}^{-1}, \mathrm{Ca}^{2+}$ concentration $0.04 \mathrm{~mol} \mathrm{~L}^{-1}$ and $\mathrm{Mg}^{2+}$ concentration $0.01 \mathrm{~mol} \mathrm{~L}^{-1}$. The minimum value of $\log K_{\mathrm{Cl}^{-}-}$ Salt $_{\min }$ is -1.80 measured by experiment.

The analysis results of variance when confidence values level $a=0.1,0.05$ and 0.01 are shown in Table 4 . As seen from the table, $F_{0.01}>F_{T}>F_{0.05}$, therefore, temperature is a very significant factor. However, the other factors are significant only when the confidence values level $a=0.1$ that they belong to significant factors. In practical application, temperature regulation should be strengthened to reduce the gas phase distribution of chloride ion.

Fig. 2 is the factors analysis on the chloride ion gas-solid phase distribution coefficient.

It can be seen from Fig. 2 that:

(1) The $\log K_{\mathrm{Cl}^{-} \text {-Salt }}=0.067$ when the temperature is $200{ }^{\circ} \mathrm{C}$, and increases to 0.848 as the temperature reaches $350{ }^{\circ} \mathrm{C}$. It illustrates that chloride ion gas-solid distribution coefficient increases with the increasing temperature. With the increase of $\mathrm{pH}, \log K_{\mathrm{Cl}^{-} \text {-Salt }}$ shows a decrease trend, the factor is 0.843 when $\mathrm{pH}$ is 3.0, and it turns to 0.232 when $\mathrm{pH}$ is 9.0. Improving the concentration of $\mathrm{Cl}^{-}$will also lead to the decrease of $\log \mathrm{K}_{\mathrm{Cl}^{-}}$Salt. It is necessary to clarify the gas phase distribution mechanism of chloride ion in high temperature liquid phase: chloride ion usually volatilizes to the gas phase in the form of $\mathrm{HCl}$ and $\mathrm{NH}_{4} \mathrm{Cl}$, but in low ammonia phenomenon, the main species is $\mathrm{HCl}$. When the concentration of $\mathrm{H}^{+}$in liquid phase agent is low, $\mathrm{H}^{+}$mainly derives from the high temperature ionization of $\mathrm{H}_{2} \mathrm{O}$ itself and the reaction is as follows:

$$
\begin{aligned}
& \mathrm{H}_{2} \mathrm{O} \rightleftharpoons \mathrm{H}^{+}+\mathrm{OH}^{-} \\
& \mathrm{H}^{+}+\mathrm{Cl}^{-}=\mathrm{HCl} \uparrow
\end{aligned}
$$

Under the condition of constant temperature, the main internal influencing factors of the above reaction are $\mathrm{pH}$ and $\mathrm{Cl}^{-}$concentration while the water contains without other impurities. When pH decreases, reaction (2) is the control step. Although it can cause the reverse movement of reaction (1) and the ionization of $\mathrm{H}_{2} \mathrm{O}$ is blocked, the total amount of free $\mathrm{H}^{+}$in the liquid phase is increased that provides adequate cation for gas phase transformation of $\mathrm{HCl}$. When there is sufficient $\mathrm{Cl}^{-}$, the reaction strength of $\mathrm{H}^{+}$and $\mathrm{Cl}^{-}$combination will improve. When $\mathrm{Cl}^{-}$concentration improves, reaction (1) becomes the control step that does not affect the chemical equilibrium, it just provides enough anions for the gas phase transformation of $\mathrm{HCl}$. When the temperature condition is constant, the free $\mathrm{H}^{+}$in the liquid phase is invariant, namely $\mathrm{Cl}^{-}$is excessive relative to $\mathrm{H}^{+}$. The macro performance is the increase of $\mathrm{Cl}^{-}$concentration makes the decrease of $\log K_{\mathrm{Cl}^{-} \text {-Salt }}$.

The reactions above are also influenced by external factors, especially temperature. The interactions between $T$-pH and $T$ $\mathrm{Cl}^{-}$concentration were studied in order to analyze the influence of temperature on chloride ion gas phase transformation comprehensively, the results are shown in Fig. 3 . The results are similar to the single-factor experiment, $\log K_{\mathrm{Cl}^{-} \text {-Salt }}$ reached the

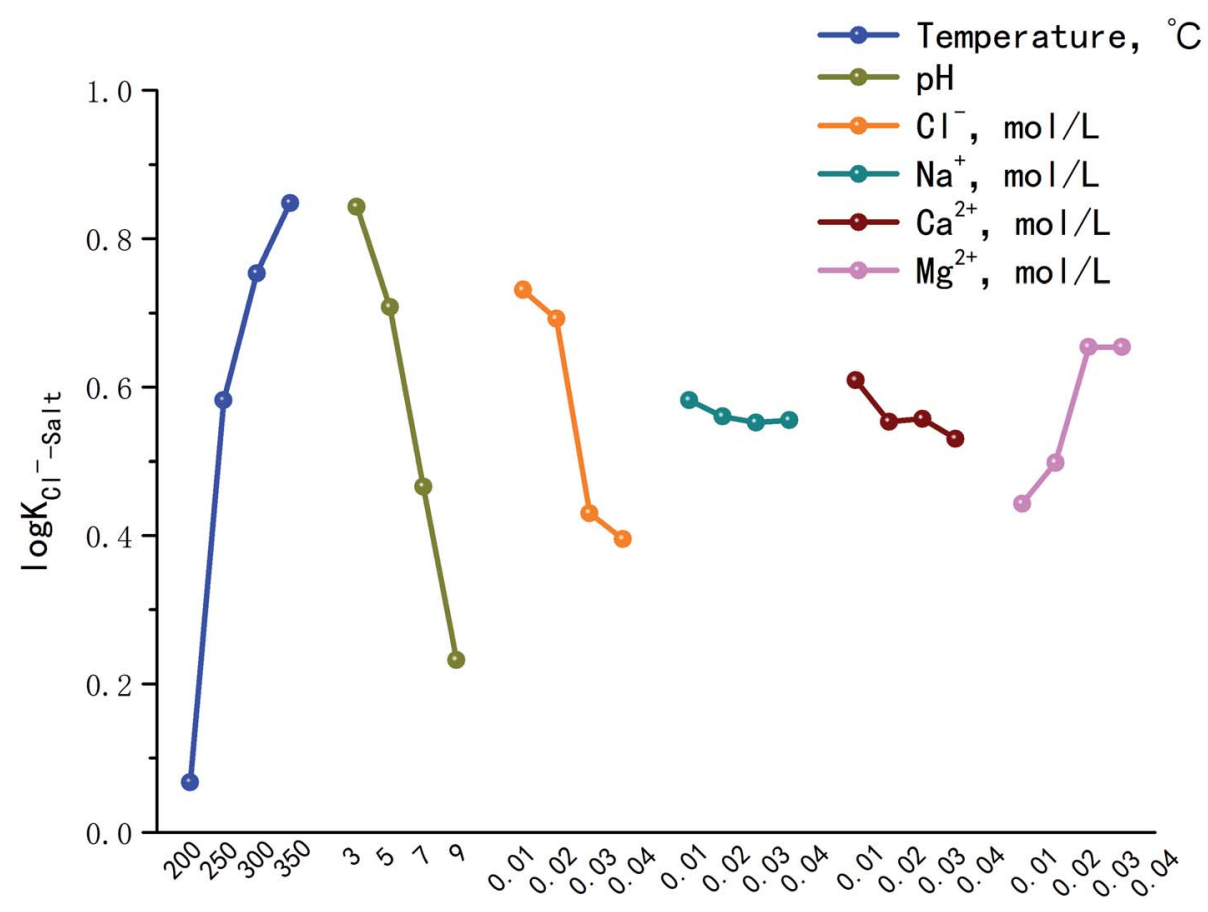

Fig. 2 Factors analysis on $\log \mathrm{K}_{\mathrm{Cl}^{-} \text {-Salt. }}$ 

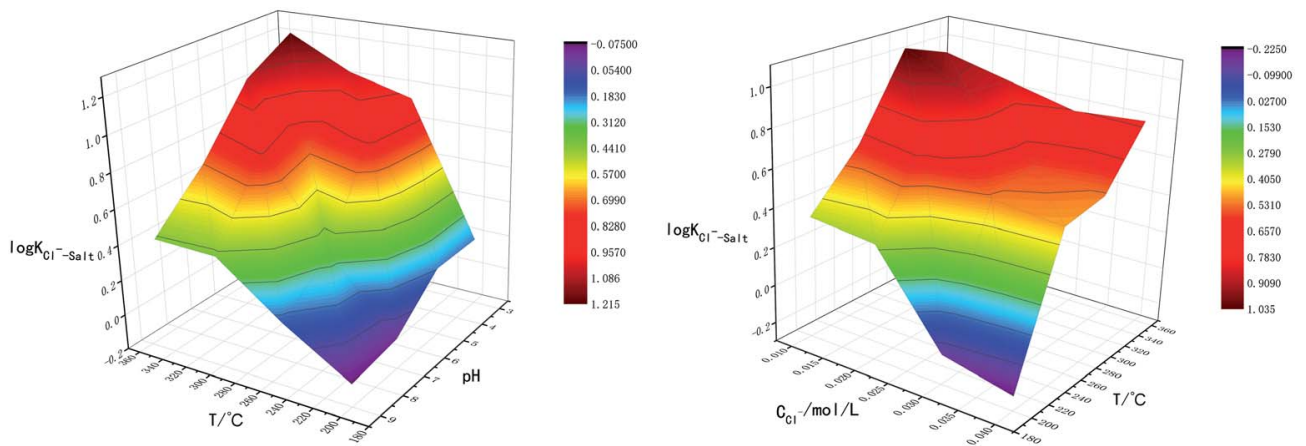

Fig. 3 Interaction between $T$-pH and $T-\mathrm{Cl}^{-}$concentration on $\log \mathrm{K}_{\mathrm{Cl}^{-}-\text {Salt }}$.

minimum value when temperature was $200{ }^{\circ} \mathrm{C}, \mathrm{pH}$ was 9.0 and $\mathrm{Cl}^{-}$concentration was $0.04 \mathrm{~mol} \mathrm{~L}^{-1}$. The effect of temperature on the gas phase transformation of chloride ion can be mainly reflected by mechanism that the temperature rise cannot promote the movement of chemical equilibrium. However, temperature rise will accelerate the reaction rate of $\mathrm{H}_{2} \mathrm{O}$ ionization, lead to increase the amount of free $\mathrm{H}^{+}$, thus chloride ion gas phase transformation is improved ultimately.

(2) The influences of main cations in desulfurization wastewater such as $\mathrm{Na}^{+}, \mathrm{Ca}^{2+}$ and $\mathrm{Mg}^{2+}$ on the chloride ion gas-solid phase distribution coefficient are discussed. It can be seen from Fig. 2 that with the increase of $\mathrm{Mg}^{2+}$ concentration, $\log K_{\mathrm{Cl}^{-}-\text {Salt }}$ increased first, then maintains constant, the maximum value was 0.654 when $\mathrm{Mg}^{2+}$ concentration was $0.03 \mathrm{~mol} \mathrm{~L}^{-1}$. However, $\mathrm{Na}^{+}$and $\mathrm{Ca}^{2+}$ inhibited the gas phase transformation of chloride ion and the difference between the two factors were not obvious. Why the three cations have different effects on $\log K_{\mathrm{Cl}^{-} \text {-Salt }}$ ? The reasons should be analyzed from two stages: liquid phase reaction and solid phase reaction.

Liquid phase reaction stages: for $\mathrm{Na}^{+}, \mathrm{Ca}^{2+}$ and $\mathrm{Mg}^{2+}$, there are two kinds of effects namely hydrolysis and cations attraction in solution. First, the three ions have different degrees of hydrolysis under high temperature conditions. Reactions are as follows:

$$
\mathrm{NaCl}+2 \mathrm{H}_{2} \mathrm{O} \rightleftharpoons \mathrm{NaOH}+\mathrm{HCl} \uparrow
$$

$$
\begin{gathered}
\mathrm{CaCl}_{2}+2 \mathrm{H}_{2} \mathrm{O} \rightleftharpoons \mathrm{Ca}(\mathrm{OH})_{2}+2 \mathrm{HCl} \uparrow \\
\mathrm{MgCl}_{2}+2 \mathrm{H}_{2} \mathrm{O} \rightleftharpoons \mathrm{Mg}(\mathrm{OH})_{2}+2 \mathrm{HCl} \uparrow
\end{gathered}
$$

$\mathrm{Ca}^{2+}$ and $\mathrm{Mg}^{2+}$ own stronger hydrolysis ability, but $\mathrm{Na}^{+}$is weaker that can even ignore. Meanwhile, $\mathrm{Na}^{+}, \mathrm{Ca}^{2+}$ and $\mathrm{Mg}^{2+}$ all have certain attraction to $\mathrm{Cl}^{-}$when the three species exist in form of free phase in solution, they will block the binding of $\mathrm{Cl}^{-}$ to free $\mathrm{H}^{+}$and inhibit formation and gas phase transition of $\mathrm{HCl}$. From the perspective of theory of ionic attraction, the anions and cations in the liquid phase are regarded as stationary point charges in the ideal liquid phase, according to the Coulombs law:

$$
F=k \frac{Q_{1} Q_{2}}{r^{2}}
$$

In the formula, $k$ represents the electrostatic constant, the value is $9.0 \times 10^{9} \mathrm{Nm}^{2} \mathrm{C}^{-2} ; Q_{1}$ and $Q_{2}$ are charged quantity of point charges; $r$ is the distance between two point charges. In liquid phase agent, the attraction order of the three cations to $\mathrm{Cl}^{-}$is $\mathrm{Na}^{+}<\mathrm{Ca}^{2+}<\mathrm{Mg}^{2+}$, namely the effect of inhibition on gas phase transformation of chloride ion is $\mathrm{Na}^{+}<\mathrm{Ca}^{2+}<\mathrm{Mg}^{2+}$.

Solid phase reaction stages: after the liquid phase reaction stages, $\mathrm{NaCl}$ itself does not form new substances; the evaporation product also exists in form of $\mathrm{NaCl}$ crystal. However, hydration occurs during evaporations of $\mathrm{CaCl}_{2}$ and $\mathrm{MgCl}_{2}$,
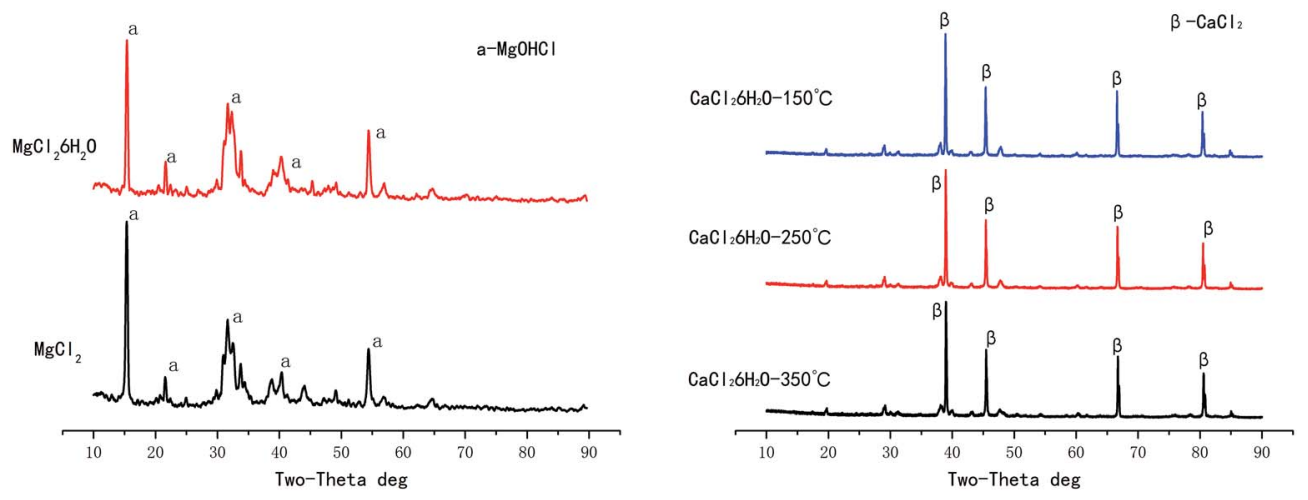

Fig. 4 The XRD diagram of hydrated magnesium chloride and hydrated calcium chloride after evaporation at high temperature. 

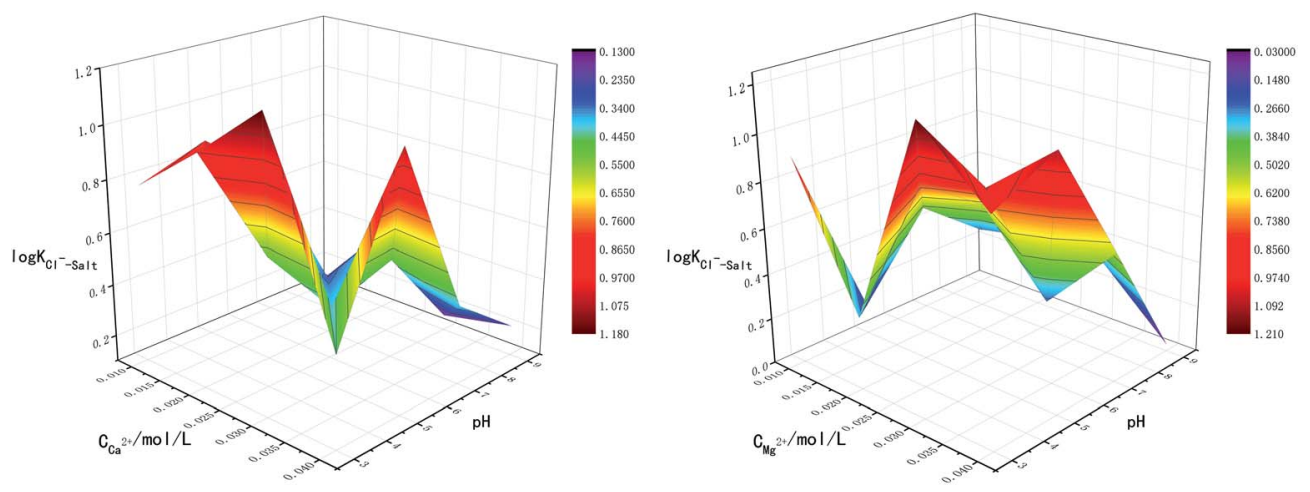

Fig. 5 Interaction between $\mathrm{pH}-\mathrm{Ca}^{2+}$ and $\mathrm{pH}-\mathrm{Mg}^{2+}$ on $\log \mathrm{K}_{\mathrm{Cl}^{-}-\text {Salt. }}$

hydrated magnesium chloride and hydrated calcium chloride are precipitated at high temperature respectively. In addition to the dehydration reaction, the solid hydrated magnesium chloride also produces hydrolysis reaction to form $\mathrm{HCl}$ in high temperature environment, while hydrated calcium chloride only loses crystal water. The XRD diagram of hydrated magnesium chloride and hydrated calcium chloride after evaporation at high temperature are shown in Fig. 4, the intermediate product $\mathrm{MgOHCl}$ is detected after hydrolysis of hydrated magnesium chloride. ${ }^{28,29}$

$$
\mathrm{MgCl}_{2} \cdot n \mathrm{H}_{2} \mathrm{O} \rightarrow \mathrm{MgOHCl}+\mathrm{HCl}+\mathrm{H}_{2} \mathrm{O}
$$

The main factors affecting the above reaction (5) and (6) are concentrations of $\mathrm{Ca}^{2+}, \mathrm{Mg}^{2+}$ and $\mathrm{OH}^{-}$. The interaction between $\mathrm{pH}-\mathrm{Ca}^{2+}$ and $\mathrm{pH}-\mathrm{Mg}^{2+}$ on $\log K_{\mathrm{Cl}^{-}-\text {Salt }}$ was explored in this experiment as shown in Fig. 5. It can be seen that the interaction between $\mathrm{pH}-\mathrm{Ca}^{2+}$ and $\mathrm{pH}-\mathrm{Mg}^{2+}$ is very complex. The increase of $\mathrm{pH}$ will increase the concentration of $\mathrm{OH}^{-}$in the liquid phase, thus causing the chemical equilibriums of reaction (5) and (6) to move reversely, inhibiting the hydrolysis of $\mathrm{Ca}^{2+}$ and $\mathrm{Mg}^{2+}$ from forming $\mathrm{HCl}$. The reason for the complex interaction is that the increase of $\mathrm{OH}^{-}$concentration will affect the solubility of $\mathrm{Ca}^{2+}$ and $\mathrm{Mg}^{2+}$ in the liquid phase. Under the common influence of the three functions of electrostatic attraction, hydrolysis and solubility, it is hardly to draw a unified conclusion now.

What's more, another essential condition that affecting the reaction rates of (5), (6) and (8) is temperature. The interaction between $T-\mathrm{Ca}^{2+}$ concentration and $T-\mathrm{Mg}^{2+}$ concentration was carried out for comprehensive analysis about the influence of temperature on chloride ion gas phase transformation. The results are shown in Fig. 6. The increase of temperature will
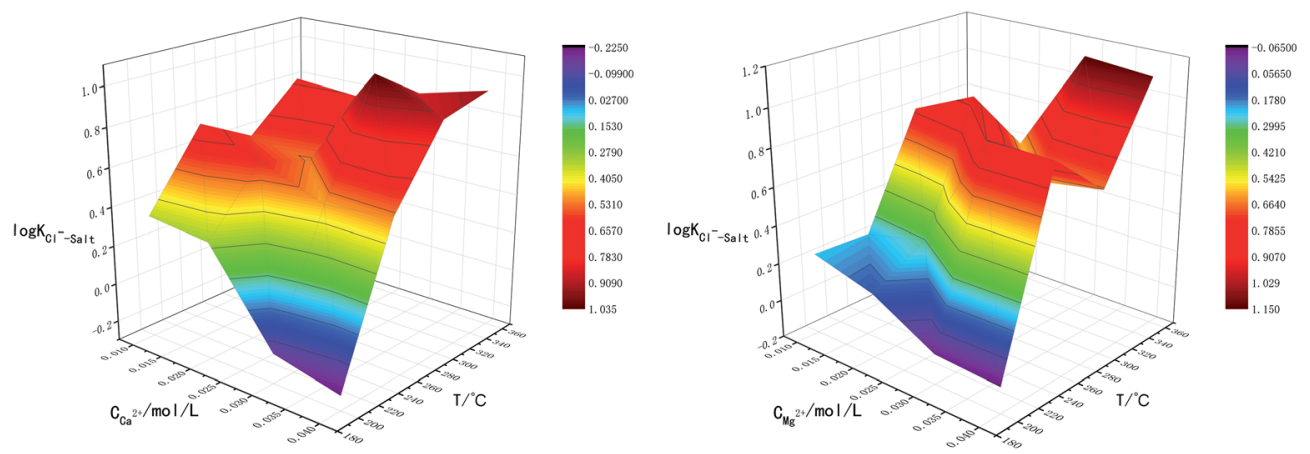

Fig. 6 Interaction between $\mathrm{T}-\mathrm{Ca}^{2+}$ and $\mathrm{T}^{2} \mathrm{Mg}^{2+}$ on $\log \mathrm{K}_{\mathrm{Cl}^{-}-\text {Salt. }}$.

Table 5 Formula fitting forms and calculation equations

\begin{tabular}{|c|c|c|c|}
\hline Empirical formula & Function & Form & $R^{2}$ \\
\hline$K_{\mathrm{Cl}^{-}-\text {Salt }}=\mathrm{e}^{a}\left(\frac{T}{100}\right)^{b} \mathrm{pH}^{c}\left(100\left[\mathrm{Cl}^{-}\right]\right)^{d}\left(100\left[\mathrm{Na}^{+}\right]\right)^{e}\left(100\left[\mathrm{Ca}^{2+}\right]\right)^{f}\left(100\left[\mathrm{Mg}^{2+}\right]\right)^{g}$ & NLINFIT & 1 & 0.8158 \\
\hline
\end{tabular}




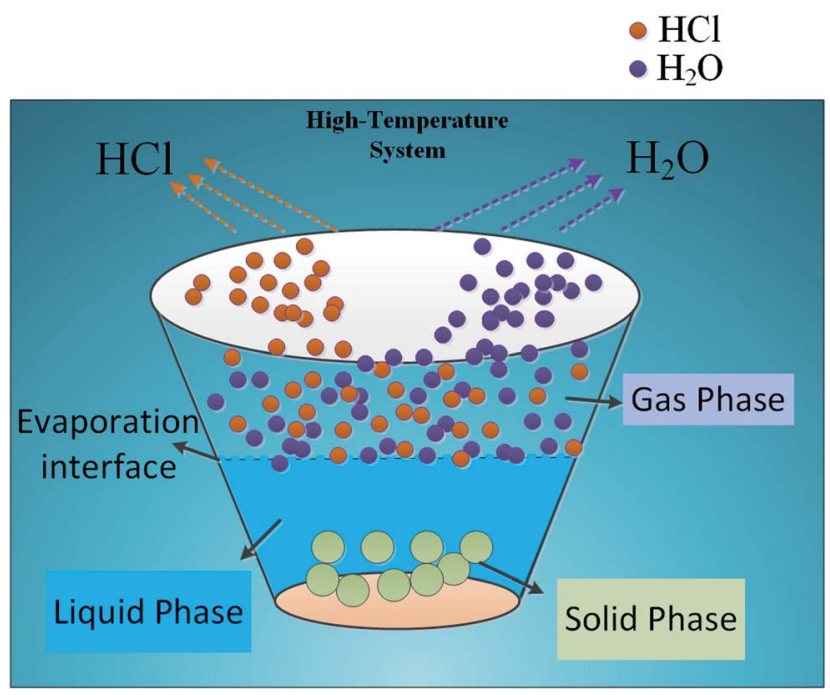

Fig. 7 Ideal mechanism of chloride gas phase transformation.

accelerate hydrolysis of forming $\mathrm{HCl}$ in different salt systems, as for hydrated magnesium chloride, the hydrolysis of solid phase can also be accelerated with the increasing temperature, thus leading to the increase of $\log K_{\mathrm{Cl}^{-} \text {-Salt }}$.

\section{Model of chloride ion gas-solid distribution coefficient}

\subsection{Fitting of empirical model}

The experimental data of orthogonal experiment were used as the source data. Multivariate nonlinear regression function of
NLINFIT and multiple linear regression function of REGRESS in MATLAB were used to calculate the fitting model, empirical formula were gotten as three forms showed in Table $5 .^{30-32}$ The results indicate that fitting degree $R^{2}(1)$ is 0.8158 and $R^{2}(2)$ is $0.8083, R^{2}(3)$ is maximum with the value 0.9258 , it illustrates that the form 3 is the most accurate and meets the calculation precision requirements.

The REGRESS function was adopted to determine the parameters in the model. Finally, an empirical model of chloride ion gas-solid distribution coefficient was obtained as shown in formula (9):

$$
\begin{aligned}
\log K_{\mathrm{Cl}^{-}-\text {Salt }} & =0.3107+0.4763 \frac{T}{100}-0.1101 \mathrm{pH}-11.35\left[\mathrm{Cl}^{-}\right] \\
& -7.7\left[\mathrm{Na}^{+}\right]+4.39\left[\mathrm{Ca}^{2+}\right]+1.94\left[\mathrm{Mg}^{2+}\right]
\end{aligned}
$$

\subsection{Correction of constant in theoretical model}

According to the theoretical model of mass transfer separation process, the chloride ion gas phase transformation was simplified as the mass transfer, heat transfer and separation process between $\mathrm{HCl}$ and $\mathrm{H}_{2} \mathrm{O}$ in the ideal $\mathrm{HCl}-\mathrm{H}_{2} \mathrm{O}$ system, the ideal mechanism is shown in Fig. $7 .^{33-35}$

The gas-solid phase distribution coefficient of chloride ion is defined as the ratio of $K_{\mathrm{HCl}}$ to $K_{\mathrm{H}_{2} \mathrm{O}}$, and the gas-solid distribution coefficient of chloride ion in $\mathrm{HCl}-\mathrm{H}_{2} \mathrm{O}$ system can be obtained:

$$
K_{\mathrm{HCl}-\mathrm{H}_{2} \mathrm{O}}=\frac{K_{\mathrm{HCl}}}{K_{\mathrm{H}_{2} \mathrm{O}}}
$$

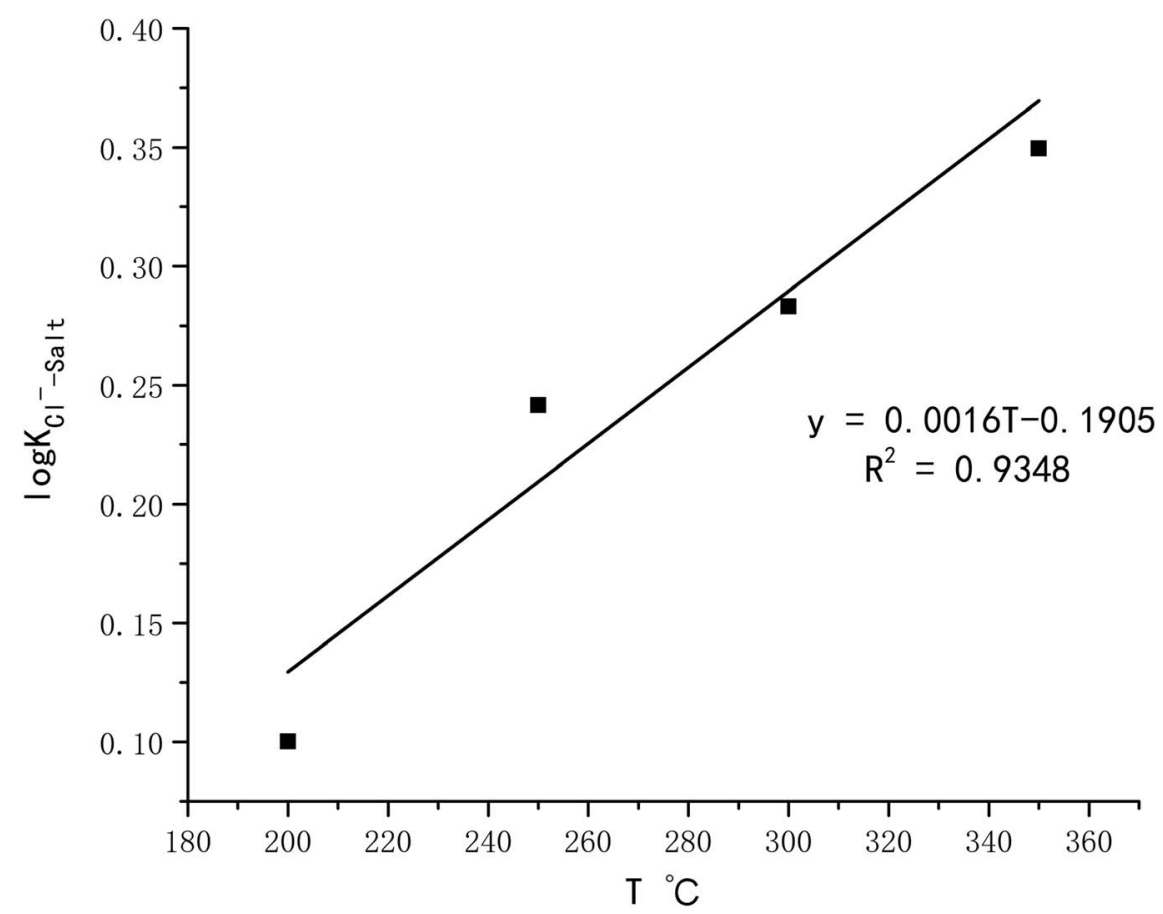

Fig. 8 Fitting of temperature correction term. 
Table 6 The comparison of heterogeneous distribution coefficient of chloride ion ${ }^{a}$

\begin{tabular}{|c|c|c|c|}
\hline $\log K_{\mathrm{Cl}^{-} \text {-Salt }}$ & Phase & $\begin{array}{l}\text { Temperature, } \\
{ }^{\circ} \mathrm{C}\end{array}$ & Researchers \\
\hline$A+\frac{B}{T}+C \log \rho_{\mathrm{w}}+D \log T$ & Gas-liquid & $50-350$ & J. M. Simonson ${ }^{19}$ \\
\hline$A+B\left(\frac{1}{T}-\frac{1}{T_{c, \mathrm{HCl}}}\right)+\log \frac{\rho_{\mathrm{w}}}{\rho_{c, \mathrm{HCl}}}$ & Gas-liquid & $250-350$ & M. S. Gruskiswicz ${ }^{22}$ \\
\hline$\varepsilon \log \frac{K_{\mathrm{HCl}}}{K_{\mathrm{H}_{2} \mathrm{O}}}+\varphi$ & Gas-solid & $180-380$ & This study \\
\hline
\end{tabular}

$K_{\mathrm{HCl}}$ and $K_{\mathrm{H}_{2} \mathrm{O}}$ are gas-liquid distribution coefficients of $\mathrm{HCl}$ and $\mathrm{H}_{2} \mathrm{O}$. Temperature $T$ was taken as the independent variable, finally, based on the phase equilibrium theory and state equation, chloride ion gas-solid phase distribution coefficient model could be calculated under temperature from $180^{\circ} \mathrm{C}$ to $380{ }^{\circ} \mathrm{C}$ as shown in formula (11):

$$
\exp \left(\log K_{\mathrm{HCl}_{-} \mathrm{H}_{2} \mathrm{O}}\right)=0.0023 T-0.334
$$

When the ideal system switches to desulfurization wastewater, the ideal state was replaced by actual system (referred to as $\mathrm{Cl}^{-}$-Salt system), the gas-solid phase distribution coefficient in actual $\mathrm{Cl}^{-}$-Salt system was listed as follows:

$$
K_{\mathrm{Cl}^{-}-\text {Salt }}=\frac{K_{\mathrm{HCl}}}{K_{\mathrm{Salt}}}=\varepsilon \frac{K_{\mathrm{HCl}}}{K_{\mathrm{H}_{2} \mathrm{O}}}+\varphi
$$

where $\varepsilon$ is the correction factor, $\varphi$ is the correction constant. If the value or expression of $\varepsilon$ and $\varphi$ were determined, the quantification and prediction of the chloride ion gas-solid distribution coefficient in process of desulfurization wastewater evaporation would be realized. The specific forms of $\varepsilon$ and $\varphi$ had been explored using actual desulfurization wastewater in previous studies. It was determined that the fitting degree $R^{2}$ between the actual state and the ideal state reached 0.9747 when the correction coefficient $\varepsilon$ was 1.068. However, the correction constant $\varphi$ was so greatly affected by the water quality of the sample solution that was unable to get a certain value. The temperature term of model (3) was subtracted from the constant term and the temperature term of model (1) and took into $T=200,250,300$ and $350{ }^{\circ} \mathrm{C}$ respectively. The linear function with the temperature $T$ as the independent variable would be obtained. The result term is defined as the temperature correction term, the form is shown in Fig. 8.

The final chloride ion gas-solid phase distribution coefficient model is showed in the form of formula (13):

$$
\log K_{\mathrm{Cl}^{-}-\text {Salt }}=\varepsilon \log \frac{K_{\mathrm{HCl}}}{K_{\mathrm{H}_{2} \mathrm{O}}}+\varphi
$$

$$
\begin{aligned}
\varepsilon=1.068, \varphi= & 0.0016 T-0.1905-0.1101 \mathrm{pH}-11.35\left[\mathrm{Cl}^{-}\right]-7.7 \\
& {\left[\mathrm{Na}^{+}\right]+4.39\left[\mathrm{Ca}^{2+}\right]+1.94\left[\mathrm{Mg}^{2+}\right] }
\end{aligned}
$$

The comparison of the calculated results for the heterogeneous distribution coefficient of chloride ion with the other similar studies is shown in Table 6 . It can be obviously seen that the experiment object of this study is aimed at the distribution of chloride ion between gas and solid phase, while the other researches focused on gas and liquid phase. The minimum temperature of the model is moderate and the maximum temperature is increased according to comparison. What's more, besides the temperature variable, the density of the liquid phase agent was used as the correction term. In this study, the temperature variables are integrated into the gas-liquid equilibrium theory, and the correction constant of model contain essential influencing factors on chloride ion gas phase transformation which is more suitable for actual operating conditions.

\section{Conclusions}

In this paper, the factors analysis on the gas-solid phase distribution coefficient of chloride ion was detected. The comparisons on the interaction and significance of each factor were analyzed by range and variance analysis. Finally, an integrated chloride ion gas-solid phase distribution coefficient model was obtained ranging from $180^{\circ} \mathrm{C}$ to $380^{\circ} \mathrm{C}$ through data fitting, the conclusions obtained are as follows:

(1) Temperature is the most dominant influencing factor for chloride ion gas-solid phase distribution coefficient, followed by $\mathrm{pH}$. In practical application, temperature regulation and $\mathrm{pH}$ control should be strengthened to reduce the gas phase distribution of chloride ion.

(2) The chloride ion gas-solid distribution coefficient increases with the increasing temperature, $\mathrm{Mg}^{2+}$ concentration and the decreasing $\mathrm{pH}$, but decreases with the increasing concentrations of $\mathrm{Cl}^{-}, \mathrm{Ca}^{2+}$ and $\mathrm{Na}^{+}$.

(3) Based on the phase equilibrium theory and state equation, chloride ion gas-solid phase distribution coefficient model was calculated ranging from $180^{\circ} \mathrm{C}$ to $380^{\circ} \mathrm{C}$, which can be used to predict the chloride ion volatilization in practical application.

\section{Conflicts of interest}

There are no conflicts to declare. 


\section{Acknowledgements}

The authors are thankful for the financial support of National Key R\&D Program of China (2018YFB0604305-01) and Central University Foundation of North China Electric Power University (2017XS124).

\section{References}

1 H. Zhang, X. F. Zhao and W. D. Zhong, Electr. Power Surv. Des., 2013, 6, 39-44.

2 C. Brogren and H. T. Karlsson, Chem. Eng. Sci., 1997, 52, 3101-3106.

3 USEPA, Pilot plant tests of chloride ion effects on wet FGD system performance, Washington, September, 1984.

4 P. Córdoba, Fuel, 2015, 144, 274-286.

5 S. Kiil, H. Nygaard and J. E. Johnsson, Chem. Eng. Sci., 2002, 57, 347-354.

6 USEPA, Steam electric power generating point source category: Final detailed study report, Washington, October, 2009.

7 Y. H. Huang, P. K. Peddi and C. Tang, Sep. Purif. Technol., 2013, 118, 690-698.

8 Y. H. Huang, P. K. Peddi and H. Zeng, Water Sci. Technol., 2013, 67, 239-246.

9 L. Cui, G. Li and Y. Li, Chem. Eng. Res. Des., 2017, 1, 240-247.

10 Y. Na, L. Fei and Z. Zhong, Ind. Eng. Chem. Res., 2010, 49, 3337-3341.

11 Ministry of environmental protection of China, http:// zfs.mep.gov.cn/fg/gwyw/201504/t20150416_299146.htm, (accessed April 2015).

12 S. Hoque, T. Alexander and P. L. Gurian, IDA J. Desalin. Water Reuse, 2010, 2, 72-78.

13 B. Pakzadeh and J. Wos, Flue gas desulfurization wastewater treatment for coal-fired power industry, ASME Power Conference, Baltimore, Maryland, America, 2014.

14 W. A. Shaw, Power, 2008, 152, 60-63.

15 H. Shintaro, S. Takeo, N. Yoshio, MHI wet-FGD waste water treatment technologies, available at http://www.aecom.com/ wp-content/uploads/2012/03/MHI-Wet-FGD-Waste-WaterTreatment-Technologies-102-AWMA-Paper.pdf,

2012 (accessed 20.12.3).

16 C. Mosti and V. Cenci, ZLD systems applied to ENEL coalfired power plants, VGB PowerTech., 2012, 92, 1-5.

17 S. Ma and J. Chai, Renewable Sustainable Energy Rev., 2016, 58, 1143-1151.
18 Ministry of Environmental Protection of China, http:// www.mep.gov.cn/gkml/hbb/bgg/201701/

t20170117_394809.htm, (accessed October 2017).

19 J. M. Simonson and A. P. Donald, Geochim. Cosmochim. Acta, 1993, 57, 1-7.

20 J. M. Simonson and A. P. Donald, Geotherm. Resour. Counc., Trans., 1998, 22, 20-23.

21 J. M. Simonson and D. A. Palmer, Office Sci. Tech. Inf. Tech. Rep., 1997, vol. 4, pp. 1-7.

22 M. S. Gruszkiewicz, S. L. Arshall and D. A. Palmer, The Partitioning of Acetic, Formic, and Phosphoric Acids Between Liquid Water and Steam, Office of Scientific Technical Information Technical Reports, Washington, US, 1999.

23 S. Q. Zhou and T. Alan, Steam Turbine Operating Conditions, Chemistry of Condensates, and Environment Assisted Cracking - A Critical Review, NPL Report MATC, Washington, US, 2002.

24 M. S. Guszkiewicz, D. B. Joyce and S. L. Marshall, The Partitioning of Acetate, Formate and Phosphates Around the Water/Steam Cycle. Office of Scientific Technical Information Technical Reports, Washington, US, 2000.

25 C. K. Liu, Group-contribution methods in estimating liquidliquid partitioning coefficients. Texas Tech. University, 1981.

26 S. Ma and W. Yu, J. Chin. Soc. Power Eng., 2016, 36, 894-900.

27 J. Otakar, Effective cycle chemistry control, ESAA Power Station Chemistry Conference, Rockhampton Queensland, Australia, 2000.

28 K. NejadS, R. Harris and K. W. Ng, Metall. Mater. Trans. B, 2005, 35, 405-406.

29 K. Nejads and R. Harris, Magnesium Technol. Global Age, Proc. Int. Symp., 2006, 1, 81-92.

30 A. Q. Rocío and M. A. García, Behav Res Methods, 2013, 45, 972.

31 J. B. Whitney and A. L. Hill, Nature, 2014, 512, 74.

32 B. L. White and H. M. Nepf, Water Resour. Res., 2008, 44, 115.

$33 \mathrm{~J} . \quad \mathrm{M}$. Smith, Introduction to chemical engineering thermodynamics. McGraw-Hill, US, 1987.

34 J. M. Walas. Phase Equilibria in Chemical Engineering, Butterworth Publishers, Boston, US, 1985.

35 K. C. Chao and R. A. Greenkorn, Thermodynamics of Fluids an Introduction to Equilibrium Theory, Marcel Dekker Inc, New York, US, 1975. 